Research Article

\title{
Overview of survey results of the Healthy Indonesia Program with a family approach in the area of Penggaron Lor, Semarang
}

\author{
Aisyah Lahdji ${ }^{1}$ \\ 1) Faculty Of Medicine Universitas Muhammadiyah Semarang
}

A R T I C L E I N F O

\begin{tabular}{ll}
\hline Submitted & : March 2019 \\
Accepted & $:$ Mei 2019 \\
Published & $:$ July 2019
\end{tabular}

Keywords:

PIS-PK, healthy family,

Penggaron Lor

\section{Correspondence:}

lahdjiaa@yahoo.com

\begin{abstract}
Health Development Index (HDI) greatly influences health status. Efforts to achieve healthy development are carried out by implementing Healthy Indonesia Program with A Family Approach (Program Indonesia Sehat dengan Pendekatan Keluarga or PIS-PK). The implementation of the PIS-PK was established with 12 main indicators, which aimed at improving the quality of life. The purpose of this study was to find out family health problems by identifying problems and analyzing the causes of health problems in the working area of Bangetayu Public Health Care (RW I, RT 5, 6, 7, 8, and 9) in Penggaron Lor, Semarang. This research is observational descriptive with a cross-sectional approach through interviews and filling in family health profile data in RW I, RT 5, 6, 7, 8, and 9. The problem obtained from the interview was an analysis of the causes of the problem using the L-Green Theory. The survey results showed that the health indexes with healthy categories consisted of 29 families, pre-healthy 113 families, and unhealthy 14 families, with three lowest indicators of PISPK are hypertension without regular medication (22\%), no family members smoke $(39 \%)$ and families join the family planning program (37\%). In conclusion, there are three problems from 12 healthy family indicators occur in Penggaron Lor, which are families who participate in the family planning program, hypertensive patients who take regular medication, and no family members who are smokers.
\end{abstract}




\section{ABSTRAK}

Derajat Kesehatan merupakan salah satu unsur penting dalam meningkatkan Indeks Pembangunan Manusia (IPM). Upaya mencapai pembangunan kesehatan dilakukan dengan melaksanakan Program Indonesia Sehat dengan Pendekatan Keluarga (PIS-PK). Penyelenggaraan PIS-PK ditetapkan dengan adanya 12 indikator utama yang bertujuan untuk meningkatkan kualitas hidup masyarakat Indonesia, dengan mengutamakan pelayanan promotif dan preventif. Tujuan penelitian ini adalah untuk mengetahui masalah kesehatan keluarga dengan mengidentifikasi masalah dan menganalisis penyebab masalah kesehatan di wilayah kerja Puskesmas Bangetayu, RW 1 (RT 5, 6, 7, 8, dan 9), Kelurahan Penggaron Lor, Semarang. Penelitian ini termasuk deskriptif observasional dengan pendekatan cross sectional melalui wawancara dan pengisian data profil kesehatan keluarga di wilayah RW I (RT 5, 6, 7, 8, dan 9). Penyebab pada masalah yang didapatkan dari wawancara dianalisis menggunakan Teori L-Green. Hasil survei menunjukkan warga wilayah RW I (RT 5, 6, 7, 8, dan 9), Kelurahan Penggaron Lor, Semarang berindeks kesehatan dengan kategori sehat sebanyak 29 Kepala Keluarga (KK), pra sehat $113 \mathrm{KK}$, dan tidak sehat $14 \mathrm{KK}$, dengan 3 indikator terendah PIS-PK yaitu hipertensi yang tidak melakukan pengobatan secara teratur (22\%), anggota keluarga tidak ada yang merokok (39\%) dan keluarga mengikuti program KB (37\%). Kesimpulan penelitian ini adalah terdapat 3 masalah dari 12 indikator keluarga sehat yang terjadi di Kelurahan Penggaron Lor yaitu keluarga mengikuti program KB, penderita hipertensi yang berobat teratur, dan tidak ada anggota keluarga yang merokok.

Kata Kunci : PIS-PK, Keluarga Sehat, Penggaron Lor

\section{INTRODUCTION}

Health degree is one of the important elements in improving the Human Development Index (HDI), but several things that affect health degree include health, environmental, health services, and community behavior. (Kozier, 2010). Efforts to achieve healthy development are carried out by utilizing all the potential to implement the Healthy Indonesia Program. The Healthy Indonesia Program is a program from Nawa Cita that aims to improve the quality of life. One of the efforts made by the Healthy Indonesia Program is through a family approach (Laelasari, Anwar, \& Soerachman, 2017). Organizing a Healthy Indonesia Program with a Family Approach is carried out by Primary Health Care. The implementation of this program aims to strengthen the function of Primary Health Care in the implementation of Community Health Efforts and Individual Health Efforts.
The Family Approach is carried out by primary health care through several activities, namely: (1) carrying out family health data collection; (2) creating and managing primary health care database; (3) analyzing, formulating, intervening and developing Primary Health Care plans; (4) conducting home visits comprehensive; (5) conduct health services; and (6) carry out information and reporting systems for Primary Health Care (Kemenkes RI, 2016).

Based on the Minister of Health Regulation of the Republic of Indonesia No. 39 of 2016 concerning the Implementation Guidelines for a Healthy Indonesia Program with Family Approach, 12 main indicators are set as markers of family health status, namely family planning, births assisted by health workers, infants receiving complete basic immunizations, giving exclusive breastfeeding, monitoring the growth of toddlers, appropriate standard medication 
for TB patients, hypertensive patients taking medication regularly, people with mental disorders getting treatment and not abandoned, none of the family members smoking, families becoming JKN members, using healthy latrines, and using water clean. (Kemenkes RI, 2016)

Penggaron Lor is one of the urban villages in the Sub-District of Genuk, Semarang, which has the smallest number of the neighborhood association, and population, which is 5943 residents consisting of 34 neighborhood association (Rukun Tetangga or RT), 5 citizens association (Rukun Warga or RW). Penggaron Lor is limited to Bangetayu Wetan, Sembungharjo, and Pedurungan (Puskesmas Bangetayu, 2018).

The objective of this study was to determine family health problems by identifying problems and analyzing the causes of health problems in the working area of Bangetayu Public Health Care, RW I and RT 5, 6, 7, 8, and 9, Penggaron Lor, Semarang with Lawrence Green Theory.

\section{METHOD}

This study was an observational descriptive study, which was conducted to describe family health in the Penggaron Lor area of Semarang with a cross-sectional design. This research was conducted in Penggaron Lor RW I and RT 5, 6, 7, 8 and 9, from February to March 2019. Data collection in this study used the Healthy Indonesia Program Family Health Profile questionnaire with a Family Approach. The data obtained is done by identifying problems and analyzing the causes of the problem.

\section{RESULT}

The area of Penggaron Lor is $1.54174 \mathrm{~m} 2$ with a population of 5,943 residents. Penggaron Lor has 34 RT, and 5 RW and the number of family cards owned is 1,537 households.
Table 1. Data on the Results of 2019 PIS-PK Penggaron Lor RW 01

\begin{tabular}{ccccc}
\hline & & \multicolumn{3}{c}{ Health Categories } \\
\cline { 3 - 5 } No & RT & Healthy & $\begin{array}{c}\text { Pre- } \\
\text { Health }\end{array}$ & Unhealthy \\
\hline 1 & 05 & 4 & 17 & 1 \\
2 & 06 & 4 & 29 & 1 \\
3 & 07 & 16 & 41 & 4 \\
4 & 08 & 2 & 12 & 5 \\
5 & 09 & 3 & 14 & 3 \\
\hline & Total & 29 & 113 & 14 \\
\hline
\end{tabular}

The results of the Healthy Family Index in Penggaron Lor RW I at RT 5 showed that there were 4 Healthy, 17 Pre-Healthy, and 1 Unhealthy family. There were 4 Healthy, 29 Pre-Healthy, and 1 Unhealthy family on RT 6. In RT 7, there is 16 Healthy, 41 Pre-Health, and 4 Unhealthy families. In RT 8 , there are 2 Healthy, 12 Pre-Healthy, and 5 Unhealthy families. In RT 9, there are 3 Healthy, 14 PreHealthy, and 3 Unhealthy families.

Table 2. Identification of problems

\begin{tabular}{|c|c|c|}
\hline No & Indicator & Achievements \\
\hline 1 & $\begin{array}{l}\text { Families follow family } \\
\text { planning }\end{array}$ & $37 \%$ \\
\hline 2 & Pregnant women do ANC & $75 \%$ \\
\hline 3 & $\begin{array}{l}\text { Babies get complete basic } \\
\text { immunization }\end{array}$ & $91 \%$ \\
\hline 4 & Exclusive breastfeeding & $61,54 \%$ \\
\hline 5 & $\begin{array}{l}\text { Toddler Monitoring and } \\
\text { Growth }\end{array}$ & $88 \%$ \\
\hline 6 & $\begin{array}{l}\text { Pulmonary TB patient who } \\
\text { seek treatment }\end{array}$ & $100 \%$ \\
\hline 7 & $\begin{array}{l}\text { Hypertensive patients seek } \\
\text { regular treatment }\end{array}$ & $22 \%$ \\
\hline 8 & $\begin{array}{l}\text { Patients with severe mental } \\
\text { disorders treated }\end{array}$ & $100 \%$ \\
\hline 9 & No family member smokes & $39 \%$ \\
\hline 10 & Families have JKN & $82 \%$ \\
\hline 11 & Have clean water facilities & $100 \%$ \\
\hline 12 & Using a toilet & $98 \%$ \\
\hline
\end{tabular}


Table 3. Theory of L-Green Hypertension

\begin{tabular}{|c|c|}
\hline Factor & Information \\
\hline \multirow[t]{3}{*}{ Predisposing Factors } & $\begin{array}{l}\text { 1. lack of knowledge } \\
\text { about the dangers of } \\
\text { hypertension }\end{array}$ \\
\hline & $\begin{array}{l}\text { 2. Know that sickness is } \\
\text { still not treatment }\end{array}$ \\
\hline & $\begin{array}{l}\text { 3. Feel healthy and get } \\
\text { well if you reduce salt } \\
\text { and cucumber } \\
\text { consumption }\end{array}$ \\
\hline Enabling Factors & $\begin{array}{l}\text { Health facilities far from } \\
\text { residents' homes }\end{array}$ \\
\hline Reinforcing Factors & $\begin{array}{l}\text { Health services are too } \\
\text { crowded and queues are } \\
\text { long }\end{array}$ \\
\hline
\end{tabular}

Table 4. L-Green Smoking Theory

\begin{tabular}{|c|c|}
\hline Factor & Information \\
\hline \multirow[t]{3}{*}{ Predisposing Factors } & $\begin{array}{l}\text { 1. Lack of knowledge } \\
\text { about the dangers of } \\
\text { smoking }\end{array}$ \\
\hline & $\begin{array}{l}\text { 2. Cigarettes are } \\
\text { provided at events at } \\
\text { the RT, RW, and } \\
\text { Kelurahan levels }\end{array}$ \\
\hline & 3. Smoking habits \\
\hline \multirow[t]{2}{*}{ Enabling Factors } & $\begin{array}{l}\text { 1. Health promotion } \\
\text { related to smoking is } \\
\text { lacking }\end{array}$ \\
\hline & $\begin{array}{l}\text { 2. No smoking area } \\
\text { available }\end{array}$ \\
\hline \multirow[t]{3}{*}{ Reinforcing Factors } & $\begin{array}{l}\text { 1. Community leaders } \\
\text { also smoke }\end{array}$ \\
\hline & $\begin{array}{l}\text { 2. Health } \\
\text { smokes }\end{array}$ \\
\hline & $\begin{array}{l}\text { 3. There are still many } \\
\text { people who smoke } \\
\text { around them }\end{array}$ \\
\hline
\end{tabular}

The table above shows that in Penggaron Lor RW I, families participating in family planning were $37 \%$, pregnant women who did ANC were $75 \%$, babies who had received complete basic immunization were $91 \%$, exclusive breastfeeding was $61.54 \%$, monitoring was growing and toddler flowers by $88 \%$. In patients with TB treatment at $100 \%$, people with mental disorders who are treated and have clean water facilities by $100 \%$. In patients with hypertension who are regularly treated by $22 \%$, families that have JKN are $82 \%$, families using latrines are $98 \%$ and family members who do not smoke are $39 \%$.

Table 5. L-Green Theory of Using KB

\begin{tabular}{lrl}
\hline \multicolumn{1}{c}{ Factor } & \multicolumn{2}{c}{ Information } \\
\hline Predisposing Factors & $\begin{array}{l}\text { 1. } \\
\text { Lack of knowledge } \\
\text { about family } \\
\text { planning }\end{array}$ \\
2. & $\begin{array}{l}\text { Fear of side effects of } \\
\text { using KB }\end{array}$ \\
Enabling Factors & - & $\begin{array}{l}\text { There is no family } \\
\text { support for using } \\
\text { family planning } \\
\text { Reinforcing Factors }\end{array}$ \\
& 2. $\begin{array}{l}\text { Want to have another } \\
\text { child }\end{array}$ \\
\hline
\end{tabular}

\section{DISCUSSION}

Based on Table 2, there were 3 major problems that appeared in Penggaron Lor, namely families participating in the family planning program (37\%), hypertensive patients who were treated regularly $(22 \%)$ and no family members smoking (39\%). The analysis of the causes of these three problems in this study used the L. Green Theory consisting of predisposing factors, enabling factors, and reinforcing factors (Green, 2011).

Table 3, 4, and 5 shows that there are several factors that influence the problems that arise in the Penggaron Lor, Semarang. The research conducted by Fauziah shows that in hypertensive problems, there is a role of families that influence influencing treatment and the influence of health workers who take good care to maintain blood pressure. Smoking problems are influenced by factors of smoking habits that are difficult to change even though posters have been given about the dangers of 
smoking (Fauziah, 2016). Other studies also show that there is a relationship between the duration of suffering from hypertension and the level of adherence to treatment (Puspita, Eka, $\&$ Yunita, 2017). The longer a person suffers from hypertension, the lower the level of medication obedience due to capacity in taking medicine while the expectations of the sufferer to recover are not appropriate (Gama, Saemidi, \& Harini, 2014). The level of knowledge also influences non-compliance in the treatment of hypertension. This is supported by research showing that there is a significant relationship between the level of education and adherence to treatment with a p-value of 0.001 (Puspita, Eka, \& Yunita, 2017). People with higher education have more knowledge than a low level of education (Notoatmodjo, 2010).

The second problem was there were still many people who smoked in their families. This is due to lack of knowledge, lack of health promotion related to smoking, important figures in the community and health workers who also smoke. Research conducted by Purnomo shows that there is a relationship between knowledge about smoking and smoking behavior, which shows a negative correlation (Purnomo, Roesdiyanto, \& Rara, 2017). There is a relationship between knowledge and smokers' behavior in implementing non-smoking areas (Kusumaningrum, Priyadi, \& Syamsulhuda, 2018). Qualitative research by Syaifulloh shows that smoking behavior is influenced by family (father and grandfather), friends and by Kiai in Islamic Boarding Schools, thus proving that the role of important figures in the community also influences smoking behavior (Syaifulloh, 2013).

The third problem found was the lack of people in using family planning. This was imposed because of a lack of knowledge about family planning, fear of side effects and lack of family support. Research conducted by
Sulikhah shows that there is no relationship between knowledge and family planning behavior, but in theory, families with a low level of knowledge do not use KB more. This is because people do not understand the importance of using KB (Sulikhah, Djiko, \& Yudhy, 2016). Other research also shows that having good knowledge means being able to understand family planning goals, methods, and side effects, although some people with good knowledge are also afraid of side effects when using contraception (Ahmadi, 2005).

\section{CONCLUSION}

In this research, there are three problems that occur from 12 healthy family indicators, namely hypertension, smoking, and family planning.

\section{REFERENCES}

Ahmadi, A. (2005). Unmet Need For Family Planning in Iran. Tehran: Tehran University.

Fauziah, A. (2016). Keluarga Sehat Berdasarkan Pendekatan Keluarga di RW 03 Kelurahan Mojosongo Surakarta Tahun 2016. Surakarta: Akademi Kebidanan Mamba'ul Ulum.

Gama, I., Saemidi, \& Harini, I. (2014, Februari). Faktor Penyebab Ketidakpatuhan Kontrol Penderita Hipertensi. Retrieved from http://poltekkes-denpasar. ac.id/files/JURNAL\%20GEMA\%20 KEPERAWATAN/DESEMBER $\% 20$ 2014/ARTIKEL\%20I\%20Ketut\%20 Gama\%20dkk,\%202.pdf

Green, L. (2011). Health Promotion Planning An Educational and Enviromental Approach. London: Mayfield Publishing Company. 


\section{QANUN MEDIKA}

JURNAL KEDOKTERAN FK UM SURABAYA

http://journal.um-surabaya.ac.id/index.php/qanunmedika

Kemenkes RI. (2016). Pedoman Umum Program Indonesia Sehatn dengan Pendekatan Keluarga. Jakarta: Kementerian Kesehatan Reupblik Indonesia.

Kozier. (2010). Buku Ajar Fundamental Keperawatan. Jakarta: EGC.

Kusumaningrum, I., Priyadi, N., \& Syamsulhuda, B. (2018). Faktor Yang Berhubungan dengan Perilaku Kepala Keluarga dalam Menerapkan Deklarasi Kawasan Dilarang Merokok (KDM). Jurnal Kesehatan Masyarakat Vol. 6, No. $5,741-750$.

Laelasari, E., Anwar, E., \& Soerachman, R. (2017). Evaluasi Kesiapan Pelaksanaan Program Indonesia Sehat dengan Pendekatan Keluarga. Jurnal Ekologi Kesehatan.

Notoatmodjo, S. (2010). Metodologi Penelitian Kesehatan. Jakarta: Rineka Cipta.

Purnomo, B., Roesdiyanto, \& Rara, W. (2017). Hubungan Faktor Predisposisi, Faktor Pemungkin dan Faktor Penguat dengan Perilaku Merokok Pelajar SMKN 2 Kota Probolinggo Tahun 2017. Fakultas Ilmu Keolahragaan Universitas Negeri Malang.
Puskesmas Bangetayu. (2018). Profil Puskesmas Bangetayu Tahun 2018. Semarang: Puskesmas Bangetayu Semarang.

Puspita, E., Eka, O., \& Yunita, D. (2017). Peran Keluarga dan Petugas Kesehatan Dalam Kepatuhan Pengobatan Penderita Hipertensi di Puskesmas Gunungpati Kota Semarang. Jurnal Kesehatan Masyarakat Indonesia , 25-32.

Sulikhah, Djiko, N., \& Yudhy, D. (2016). Hubungan Beberapa Faktor Pasangan Usia Subur (PUS) dengan Unmet Need Keluarga Berencana (KB) di Desa Penungkulan Kecamatan Gebang Kabupaten Purworejo Tahun 2016. Jurnal Kesehatan Masyarakat Vol. 5, No. 4, 265273.

Syaifulloh, N. (2013). Studi Peranan Tokoh Agama dan Perilaku Merokok Santri di Pondok Pesantren Al-Islah Desa Bandar Kidul Kecamatan Mojoroto Kota Kediri. Jurnal Promosi dan Pendidikan Kesehatan Indonesia Vol. 1, No. 2, 124-131. 